\title{
Needs assessment of model career bases intervention as a traverse for Culinary Vocational Education graduates' work readiness
}

\author{
Kokom Komariah, Fitri Rahmawati, Minta Harsana \\ Faculty of Engineering, Universitas Negeri Yogyakarta \\ Yogyakarta, Indonesia \\ kokom@uny.ac.id
}

\begin{abstract}
Preparing the workforce who can be employed in the industry is the ultimate mission of vocational education. Therefore vocational education has to engage the learning model which is able to deliver the graduates to be ready to work. The study aims to strain the needed information which can be used as a base for designing the model Career Based Intervention (CBI) as a traverse to manage graduates' work readiness. This study is a research \& development, referring to the Borg and Gall (1989) because it will be used to develop a model that will be generated. Needs assessment is a part of this research stage. Subjects were practitioners of the field of catering industry and academia related vocational education amounted to 20 people. Data collection through focus group discussions (FGD). Data were analyzed using descriptive qualitative. Qualitative analysis is described through a clear and logical narrative, analyzed, classified according to the thematic. Research results illustrate that the materials that need to be included in the design of the CBI models include (1) Orientation and information world of work; (2) The introduction of self-efficacy; (3) Skills achieve selfemployment and development in the world of work. Solutions offered for implementation by providing learning tools in the form of modules and worksheets, and use of innovative learning methods that can help to explore the potential and understanding self-learners.
\end{abstract}

Keywords: needs assessment, intervention bases career, job readiness graduates

\section{INTRODUCTION}

Improving the quality of human resources development should be a priority of the Indonesian nation today. 2015 Indonesia has entered the era of ASEAN Economic Community (AEC) so that the labour sector will be a major focus. In the era of industrialization and globalization many changes in life that happen quickly, so sue humans have the ability to cope with change. Efforts to improve the quality of human resources is the promotion of quality education, good basic education level to higher education.

Shafiq (2014) suggested that higher education in Indonesia is currently the ace in the achievement of national goals educating the nation. Therefore, higher education has a function to increase the quantity and quality of society, so that it becomes a solid foundation for building the nation. Various attempts have been taken by the government to improve the quality of education, such as curriculum development, faculty competence improvement, through training, provision of books and learning tools, procurement and improvement of educational facilities. However, the quality of national education remains poor, appropriate solutions to improve the quality of education has not been found.

Data central bureau of statistics 2012, stated that 7,419,481 people graduate from universities, as many as 421,717 are still unemployed. The unemployment rate is a symptom of oversupply, that the growth of the labour force is much greater than the growth of employment. (Depdiknas, 2009)

The phenomenon of many college graduates is not absorbed in the world of work, requiring a change in the pattern of arrangements for education so as to improve the response to various challenges. Currently, the public awareness of the importance of higher education with a better system is increasing. Current situation by Shafiq (2014) there is two major groups. First massification higher education characterized by the number of universities has increased. This is caused by the ability and demand of the public for higher education increased, strengthening formal recognition of knowledge and experience, the demands on the significance of the educational with socio-economic status, and the presence of the paradigm "knowledge society in the context of knowledge economy". Both the existence global dynamics causing increasing competition between universities, regional and international competition increases and the demand for college graduates employability through learning activities.

The situation caused a challenge for college that must be answered, in the perspective of higher education with the world of work how universities play a role in preparing graduates for immediate employment, in this case, the higher education needs to emphasize the importance of gaining knowledge in relation to the description of the task in the world work.

Various perspectives of higher education with the world of work has to parse the importance of mastery of competencies, both the nature of hard skills, as well as soft skills. Marwanti \& Yuriani (2008) states that the importance of the ability of graduates for Hospitality Studies Program is to master production competence, services, and managerial. While aspects of employability skills have been identified by 
Komariah, (2013) is covering aspects of reliability in work, ability to cooperate, reasoning ability, initiative, interest, independence, courtesy, discipline, and the ability to react to criticism and suggestions.

Based on this vocational career guidance is very important. This program has been implemented through learning, but still very diverse patterns of implementation. A learning model for the implementation of career guidance course no one has proven through research, perspectives on the market job are still very limited, so the insights of students to be lived career ahead is still limited anyway. Hospitality Studies Program graduates are still perceived to be limited to the culinary field in restaurants and hotels or working as a teacher of vocational education at various levels of education.

Related to the role of higher education as stated above, it is necessary to intervene career learning models through the course. Some information that can be used as a reference is needed to produce a learning model that can be used as a bridge to enter the workforce.

\section{MATERIAL AND METHOD}

Work can be function tp gives the values and the expected happiness of themselves and society. There are many reasons why people should work. Working for yourself is for satisfaction, security, financial independence, selfimprovement, improvement of living standard, and self-esteem. As for community work is a source of income, as time and money, and means of enhancing career and personality. (Winata W, 1979: 54-59).

The difficulty a person gets a job has been proposed by Hurlock, since 1994, caused by many things: (1) the number and types of different jobs that would have been growing; (2) the demands of the rapid changes in the needs for skills and knowledge required; (3) the level of the low flexibility of working time makes women difficult to adjust to the schedule office work and chores at home; (4) the need to prepare a long and costly to establish a career so it is difficult for a person to change his career; (5) positions and specific task is seen as a special work for women, and certain occupations considered a man's job; (6) certain jobs are considered very pleasant and certain jobs are considered unpleasant; (7) who have less employment security guarantees; (8) lack of experience and training acquired; (9) education and training are not eligible; (10) target majors obtained from childhood to adulthood is not realistic; (11) the value and unrealistic expectations. (Hurlock, 1994: 280)

The results of tracer studies for graduates in 2011, Yogyakarta State University, conducted by Harsana (2013), showed that $40 \%$ of graduates do not work in accordance with their fields, and $19.46 \%$ of graduates are still looking for work. Likewise, how graduates get jobs is still very diverse

Prihastuti and Komariah (2009: 34) indicate that the order of priority based on the general competencies required by DUDI first is the attitude, the second appearance/performance, the third knowledge, and all four skills. Based on this, is very natural that in the business world attitude and performance competencies more important than other competencies.

Career-based intervention study conducted at Ohio State University (2011) apply the objective as follows: (1) Solve work-related problems and make-work related decisions; (2) Apply basic communication skills; (3) Read for information and understanding; (4) Use of research and writing skills to present individual projects; (5) Follow written and oral instructions; (6) Exhibit desirable personal and professional attitudes and behaviors; (7) demonstrate job-keeping skills; (8) demonstrate work ethics at the work site; (9) demonstrate knowledge of proper Seeking job skills; (10) Make informed financial decisions; (11) Demonstrate leadership and leadership strategies; (12) demonstrate technology skills; (13) Use word processing, and power points to Accomplish a variety of purposes; (14) Build interpersonal skills, with different ages, abilities and genders; (15) Manage conflict and stress; (16) Investigate career options; (17) Participate in job shadowing experience; (18) Pass a basic safety test; (19) Use proper strategies for dealing with differences associated with diversity; (20) Use spreadsheets to keep track of hours and pay; (21) Participate in the end of the year Employee Appreciation Breakfast and award presentation. (Pinchak, 2011)

A study has been carried out based on research conducted by Komariah (2013) identifies aspects of employability skills needed in the work include aspects of reliability in work, ability to cooperate, the ability to make a judgment, initiative, interest, independence, courtesy, discipline, and the ability to react to criticism and suggestions. So, on these aspects can be drilled through the learning model of work-based learning.

Some sources say that the power of career guidance are: (1) to contribute directly so that a person has career decisions and actions. (2) increased confidence and security when facing role and organizational change; (3) leads to job satisfaction to a higher level if someone is developing a career in his work; (4) an increase in performance, and contribute to the formation and fulfilment are more realistic in psychological contract. (Cuningham, Dawes and Bennett, 2004: 67)

While the purpose of the Career-Based Intervention (CBI) expressed in the local school district licking heights (2011) is the Career-Based Intervention help students with barriers to career and academic success improve academic competencies, graduate from high school, developing employability skills, implement a career plan, and Participate in a career pathway in preparation for postsecondary education and careers.

\section{METHODS}

This study is part of the research \& development, as it will be used for the development of a model that will be generated. Needs assessment for the development of models of careerbased intervention to prepare graduates who are ready to work is the main activity of this research. Subjects were practitioners of the field of catering industry and academia related vocational education amounted to 20 people. Data collection through focus group discussions. Data were analyzed using descriptive qualitative. Qualitative analysis is described 
through a clear and logical narrative, analyzed, classified according to the thematic.

\section{RESULTS}

\section{A. The Material that needed for Career Based Intervention Model Implementation}

The results of the study indicate where the materials needed as a basis for the design of career-based intervention models include (1) Job market orientation and information, (2) selfefficacy, and (3) reached skill and development of selfemployment. While the solutions for the design of career-based intervention models are: (1) prepare a learning device in the form of modules that provides information about the world of work, and guidelines are able to bring student learning to recognize himself. (2) using the relevant learning strategies such as job showing, field trips, discussions, simulations, games, case studies and assignments.

The following aspects can be identified to be used as the design model of career-based intervention for students in vocational education are presented in the following table

TABLE 1: JOB MARKET ORIENTATION AND INFORMATION

\begin{tabular}{|c|c|}
\hline No & Material \\
\hline 1. & Information about required competencies \\
\hline 2. & $\begin{array}{l}\text { Industry recognition orientation, (facilities, management, } \\
\text { organization, rules.) }\end{array}$ \\
\hline 3. & Orientation about the type of work that graduate can enter \\
\hline 4. & Information about the job requirements \\
\hline 5. & $\begin{array}{l}\text { Information about wages and salaries, social security, layoffs, } \\
\text { and worker's organizations }\end{array}$ \\
\hline 6. & Information values and rules contained in career choice (work \\
\hline & The local labour market information \\
\hline 8. & International labour market information \\
\hline 9. & Information advantages and constraints of doing business \\
\hline 10. & Identify the main job skills/core \\
\hline
\end{tabular}

Based on the results of the Focus Group Discussion, orientation and job market information can identify 10 (ten) the material that needed among other the competencies required information, industry recognition, information about the industry and policy constraints commonly encountered in running the business.

TABLE 2: SELF-EFFICACY

\begin{tabular}{|c|l|}
\hline No & \multicolumn{1}{|c|}{ Material } \\
\hline 1. & Know your own potential \\
2. & Understand their own personality \\
3. & Identify self-motivation \\
4. & Looking at the performance of yourself \\
5. & Looking at their own academic abilities \\
6. & Understand our own self-skills \\
7. & Tip talents and interests \\
8 & Understand their dream job \\
\hline
\end{tabular}

The second aspect after it was discovered that the necessary introduction grouped themselves capabilities. The identification results found that there are eight (8) items themselves need to be included recognition capabilities through career-based intervention models. Furthermore, the third grouping is obtained based on the identification and development of work skills earned yourself in the market job, as directed as follows.

TABLE 3: REACHED SKILL AND DEVELOPMENT OF SELF-EMPLOYMENT

\begin{tabular}{|c|l|}
\hline No & \multicolumn{1}{|c|}{ Material } \\
\hline 1. & The ability to conduct an interview with a well \\
2. & Ability to make curriculum vitae well \\
3. & The ability of expression \\
4. & Keeping value friendship and harmony in interacting with \\
5. & others \\
6. & Develop and maintain the values of the association in the \\
7. & workplace \\
& Assessing objectively feelings of self and others \\
8. & Convinced and develop unique self as assets that must be \\
9. & developed in the life \\
10. & Affirming the values of life-saving, tenacious, no-Sunggu, and \\
11. & competitive \\
12. & Maintain the independence of behaviour \\
13. & Understanding gender in job \\
& Comply with the rules of the company \\
& Ability to decision-making \\
\hline
\end{tabular}

There are 13 (thirteen) items acquired, things are put into this aspect includes the ability to conduct interviews, the ability to make good curriculum vitae, and social skills such as socializing, communicating, and personal abilities such as selfreliance, and discipline.

\section{B. Achieve Solutions Work Readiness Through Career based Intervention Model}

Several solutions were obtained through theoretical studies and empirical studies through FGD, the solution proposed by the model Career-Based Intervention (CBI) CBI as the model assumption that treatment can be used as a bridge to reach job readiness for vocational education students.

Information needed in the workplace studied first, then do the introduction of self through a variety of learning strategies that are considered suitable, and then introduced through obtaining and developing job. Information needed in the workplace can be understood through learning activities. In an effort to help this learning module is required. Intervention on self-introduction can be achieved through learning strategies and tools that can help students to recognize the potential of self, and. take job skills and personal development in the world of work assisted through the development of case examples, and practical problem-solving.

Alternative learning solutions with the Career-Based Intervention models are expected to be a bridge in the formation of graduate employment readiness. A variety of information about the world of work, introducing themselves, and reach out and develop job skills, after grouping and look for a solution can be described as follows. 


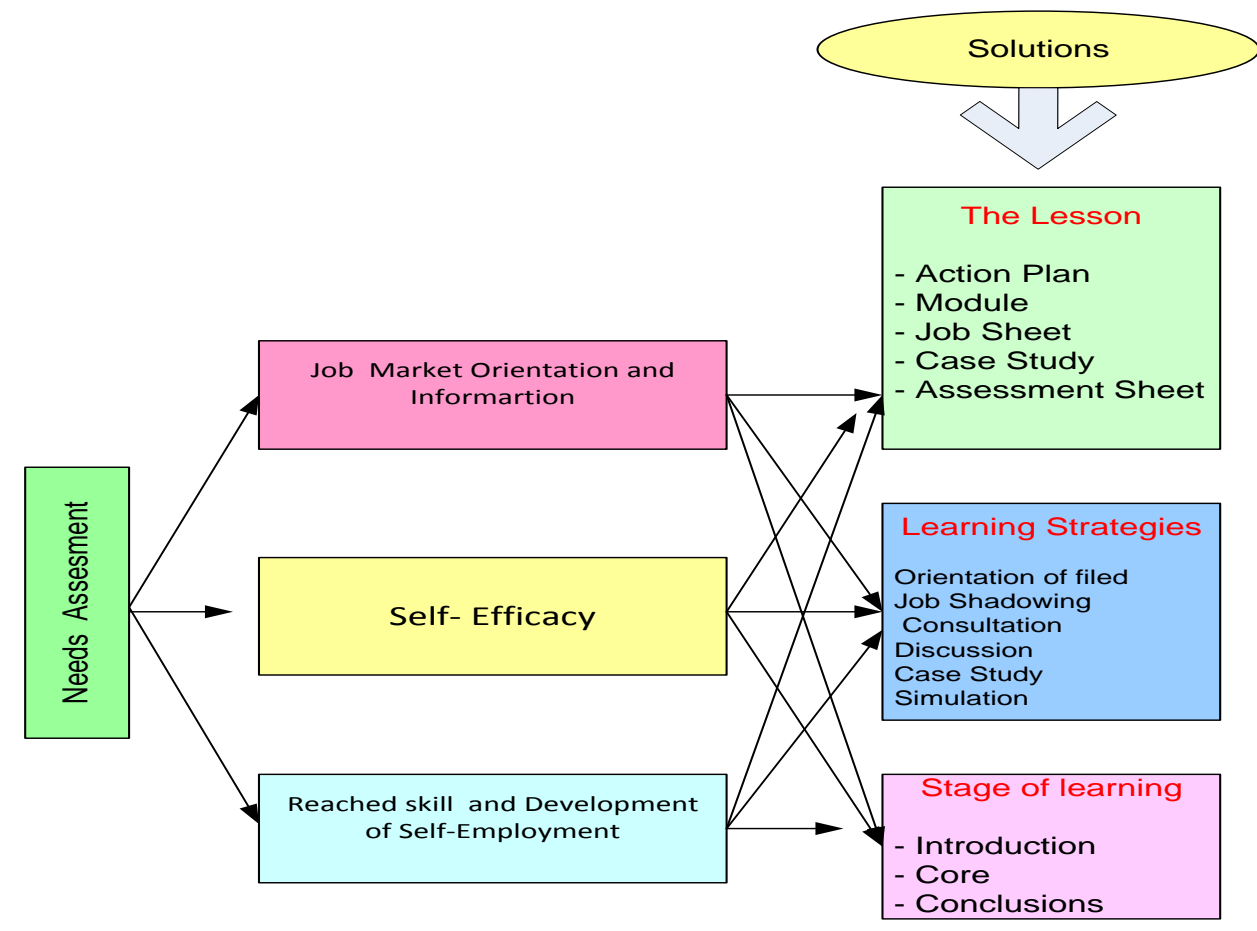

Fig. 1. Components Needed in CBI Model and Prediction Method Achieving

\section{CONCLUSION}

The results of this study illustrate that the materials that need to be included in the design of the CBI models include (1) Job market orientation and information; (2) The introduction of self-efficacy; (3) Reached skill and development of selfemployment. The reason this is still to think more about how to put it in the learning activity because it may not be all of them can be followed up in a learning device that became a model CBI.

The solution offered as an effort to achieve these competencies is to strengthen the implementation of learning by providing learning tools in the form of modules that provide information about the world of work, learning tools such as worksheets; (2) the application of methods and learning strategies that can explore the potential and self-understanding, and (3) take a job skills and personal development assisted through the development of case examples, and practical problem solving. This new solution at the level of the concept, the question is whether the model can be built effectively to bridge the readiness of graduates works still needs to be tested effectiveness.

\section{REFERENCES}

[1] Borg, W R \& Gall, MD. (1998). Educational research. New York: Longman.

[2] Cuningham I, Dawes G, and Bennett B.( 2004). The Handbook of Work Based Learning. Burlington: Gower Publishing Company
[3] Depdiknas. ( 2009). Teropong Wajah Sekolah Menengah Kejuruan di Indonesia. Jakarta: biro Perencanaan dan Kerjasama Luar Negeri Sekretariat Jendral Kementrian Pendidikan Nasional.

[4] Gysbers, N.C, Heppner M J. Johnston J.A (2003). Career Counseling Proses, Isuues, and Techniques. Boston: Pearson Education, Inc

[5] Harsana, M. (2013) Tracer Study Alumni S1 Universitas Negeri Yogyakarta Tahun 2011. Yogyakarta: Universitas Negeri Yogyakarta.

[6] Herr, E. L. Cramer, S H. Niles. (2004). Career Guidance and Counseling. Through the Lifespan. Boston: Pearson Education, Inc

[7] Hurlock, E. (1994). Psikologi Perkembangan. Jakarta: Erlangga. Indonesia.

[8] Komariah. K (2013). Pengembangan Model Pembelajaran Pengolahan Makanan dalam Konteks Work-based Learning di Industri Hotel bagi Mahasiswa Program Diploma III. Disertasi. Yogyakarta: Program PPS Universitas Negeri Yogyakarta.

[9] Pinchack.J. (2011). Syllabi Course. Departement Workforce Development and Education section (WDE). Columbus: Ohio State University.

[10] Prihastuti E \& Komariah, K (2009). Analisis kompetensi kunci bidang kerja restoran dengan pendekatan responsif evaluation untuk meningkatkan kualitas lulusan mahasiswa pendidikan teknik boga. Laporan Penelitian. Yogyakarta: FT UNY

[11] Syafiq. A (2014). Urgensi Tracer Studi dalam Penjaminan Kualitas Perguruan Tinggi. Makalah disampaikan di Universitas Negeri Yogyakarta: Yogyakarta: Pusat Pengembangan Karier LPPMP

[12] Winata W.(1979). Orientasi Kerja. Jakarta : Departemen Pendidikan dan Kebudayaan. 